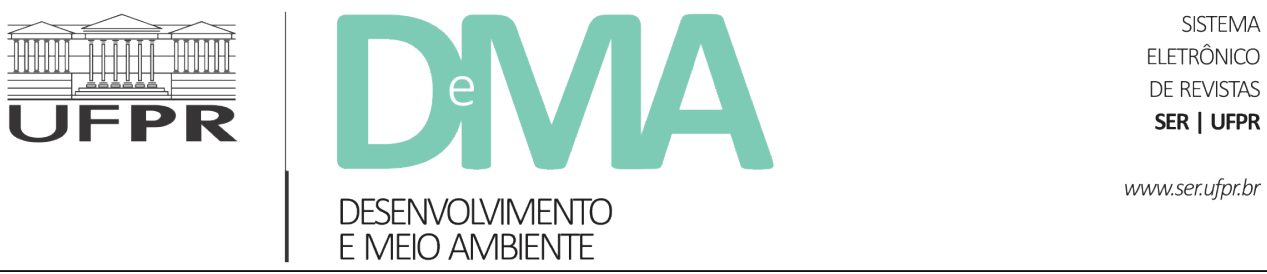

\title{
Making and making use of a baseline: botanical research and the legacy of Chico Mendes
}

\section{Elaborando e utilizando uma linha de base: pesquisas botânicas e a herança de Chico Mendes}

\author{
Douglas Charles DALY ${ }^{1 *}$, Marcos SILVEIRA², Flávio Amorim OBERMÜLLER ${ }^{3}$ \\ ${ }^{1}$ New York Botanical Garden, New York, U.S.A. \\ ${ }^{2}$ Universidade Federal do Acre (UFAC), Rio Branco, AC, Brazil. \\ ${ }^{3}$ Programa de Pós-Graduação em Ecologia, Universidade Federal do Rio de Janeiro (UFRJ), Rio de Janeiro, RJ, Brazil \\ *E-mail of contact: ddaly@nybg.org
}

Article received in April 9, 2018, final version accepted in August 21, 2018.

ABSTRACT: The vision and charisma of Chico Mendes made Acre a destination for many people fascinated and inspired by the great socio-environmental experiments he was proposing; his murder only increased that interest. The extractivist movement engendered by Chico Mendes, with a potentially strong role for basic research, was the primary reason that The New York Botanical Garden (NYBG) committed scientists and resources in order to study the flora of Acre and Southwestern (SW) Amazonia. At the outset of our collaborative agreement with the Universidade Federal do Acre (UFAC)[Federal University of Acre], Acre was botanically one of the least-known parts of Amazonia. Thirty years later, it has come to be one of the best-known parts, due in great part to the First Catalogue of the Flora of Acre, Brazil, which contributed with the first ten percent of the checklist to the flora of all Brazil. More importantly, we were able to add original data to arguments for the making of new protected areas in Acre. In these process, we established Acre as a point of reference for botanical knowledge about Southwestern Amazonia. The NYBG/UFAC partnership was an early participant in the MAP (Madre de Dios-Acre-Pando) consortium and helped designate priorities portions of SW Amazonia to conservation. Our botanical research in this region has emphasized potential applications to resource management. Most recently, our efforts have focused on reforming forest management and monitoring by continuing to build on our baseline of knowledge of the flora, proposing better protocols for sampling and collection in forest inventories, offering training courses to the certification of new generations of "master woodsmen", and developing tools and resources for tree identification. Our capacity-building efforts now focus primarily on communities situated in or close by 
protected areas, treating them as participants and collaborators in forest inventory and monitoring. Making good use of traditional knowledge and focusing on forest communities as full participants and partners in projects devoted to inventory, management, monitoring and conservation of forests throughout Amazonia, we are doing our small part to honor the legacy of Chico Mendes.

Keywords: Amazonia; botanical research; floristics; resource management; taxonomy.

RESUMO:

A visão e o carisma do Chico Mendes fez do Acre um destino para muitas pessoas fascinadas e inspiradas pelos grandes experimentos socioambientais que ele propunha; o assassinato dele só aumentou esse interesse. O movimento extrativista gerado por Chico Mendes, com um papel potencialmente forte para pesquisa básica, foi o motivo principal para o qual o New York Botanical Garden (NYBG) comprometeu pesquisadores e recursos para estudar a flora do Acre e do Sudoeste da Amazônia. No início do nosso convênio com a Universidade Federal do Acre (UFAC), botanicamente o Acre era uma das áreas menos conhecidas da Amazônia. Trinta anos depois, ficou sendo uma das mais conhecidas, devido em grande parte ao Primeiro Catálogo da Flora do Acre, Brasil, que contribuiu com os primeiros $10 \%$ do checklist para a flora do Brasil inteiro. Mais importante, conseguimos acrescentar dados originais aos argumentos para a criação de novas áreas protegidas no Acre. Neste processo, tornamos o Acre um ponto de referência para conhecimento botânico sobre o Sudoeste da Amazônia. A parceria NYBG/UFAC foi um participante no consórcio MAP (Madre-de Dios-Acre-Pando) e ajudou a designar porções dessa região prioritárias para conservação. As nossas pesquisas nesta região têm enfatizado aplicações potenciais no manejo de recursos florestais. Mais recentemente, os nossos esforços têm enfocado em reformar práticas de manejo florestal e em continuar a construção de uma base de conhecimento da flora, propondo protocolos melhores para amostragem e coleção em inventários florestais, oferecendo cursos de treinamento para certificação de novas gerações de "supermateiros," elaborando ferramentas e recursos para a identificação de árvores. Atualmente, os nossos esforços na capacitação enfatizam principalmente comunidades localizadas em ou próximas a áreas protegidas, considerando-as como participantes e colaboradores em inventários florestais e monitoramento.

Aproveitando o conhecimento tradicional e enfocando nas comunidades florestais como participantes e parceiros integrais em projetos dedicados a inventários, manejo, monitoramento e conservação de florestas em toda a Amazônia, estamos cumprindo o nosso modesto papel em honrar a herança de Chico Mendes.

Palavras-chave: Amazônia; pesquisa botânica; florística; manejo de recursos; taxonomia.

\section{Introduction}

The New York Botanical Garden (NYBG) has studied the Amazon flora since the 1880 s, and it has maintained collaborations with multiple Brazilian scientific institutions continuously since the 1960s (Daly \& Lisboa, 1991 (1993)). In 1989, not long after Chico Mendes was assassinated, Marianne Schmink, from the Center for Latin American Studies at the University of Florida, invited NYBG and the Wildlife Conservation Society to convene a meeting at the latter's offices to try and stimulate interest in the state of Acre, where she had already been working for some time with forest communities and the Rubber-Tapper movement. She understood that extractive reserves and sustainable management of forest resources in general require solid scientific knowledge of such resources. Her visit came at a very opportune moment, as it coincided with the conclusion of ten years of continuous support from the U.S. National Science Foundation for Projeto Flora Amazônica, a Brazil-based international effort 
to collect plant specimens throughout the Brazilian Amazonia and establish a foundation for more in-depth study (e.g., Prance et al., 1984).

The idea of being able to build on a baseline and use it to contribute directly to the vision of Chico Mendes in a region that was almost completely unknown biologically was powerfully attractive (Daly, 1990), and those who participated in botanical efforts over the next 30 years were committed to conduct botanical research whose results could aid in the diversification of extractive economies and sustainable management of forest resources. Subsequent years would yield a number of experiences and experiments in the interactions of social movements and conservation, of development and in the environment, of research and resource management, of basic research and sustainable development. It was thanks to Chico Mendes that NYBG came to Acre and was able to recruit the key researchers who made the botanical achievements possible. It was thanks to the international outcry following his death that Acre was a safe place for someone to be an organizer, a journalist, or a biologist.

\section{Building the baseline}

When NYBG first arrived in Acre, it was an unexplored black hole, not only of botanical knowledge but also of human resources and infrastructure for botanical research. The herbarium of the Universidade Federal do Acre (UFAC) had been closed for several years, and it contained fewer than 3,500 specimens, most of them sterile inventory collections of poor quality. Communication and transportation were precarious and often impossible. Still, the herbarium existed, and UFAC was an enthusiastic and appropriate partner for a research-based initiative.

Nívia Maria de Paula Fernandes, a biology professor at the Universidade Federal do Acre-UFAC, can be credited with both re-opening the herbarium and developing the first collaborative agreement with NYBG, and early on the NYBG-UFAC consortium was able to recruit two researchers who were the primary factors in most subsequent flora-related successes that were achieved in Acre. Prof. Lin Chau Ming came to Acre in 1991 while still a master's student at the Universidade Federal do Paraná (UFPR) [Federal University of Paraná] in Curitiba because he wanted to study the use of medicinal plant in extractive reserves, although eventually his permanent base was the Universidade Estadual Paulista (UNESP) [State University of Sao Paulo] - Botucatu. That same year, he convinced a classmate in Curitiba, Marcos Silveira, to apply for an opening to be a professor at UFAC.

Despite the fact that medicinal plant research in Brazil was a hypersensitive issue and was especially under the microscope in Acre, Lin Chau Ming's history as a social movements organizer won the trust of the Conselho Nacional dos Seringueiros (National Council of Rubber-Tappers), and while maintaining his base in Botucatu, he went on to conduct significant ethnobotanical studies in Acre (Elisabetsky et al. 1995; Ming et al., 1997; Ming et al., 2006; 2007), many of which have come to fruition as publications recently (Siviero et al., 2016; Ming et al., 2018a; 2018b), and to support large numbers of undergraduate and graduate students in ethnobotany. One book on medicinal plants used in the Chico Mendes Extractive Reserve was co-authored by him and his two principal rubber-tapper collaborators (Ming et al., 1997). Marcos Silveira 
became the UFAC counterpart for its long-term collaborative agreement with NYBG.

The umbrella title for all of the activities in Acre was Floristics and Economic Botany of Acre, Brazil. Early on, it became clear that perspectives and experiences from the outside would give the participants in the NYBG-UFAC program a better idea of what was possible, so in 1990 the NYBG-UFAC consortium secured a grant to bring the entire Biodiversity graduate program of the Federal University of Minas Gerais (including professors) to offer a week-long course in biodiversity field techniques. In addition, for the first botanical expeditions the consortiuminvited an entire field team from INPA composed of veterans from Projeto Flora Amazônica, to show how a highly productive expedition could be run.

Botanical exploration of the state began right away, but much of the initial investment was in "rescuing" and integrating all existing information about the flora of Acre, from publications, correspondence, and far-flung herbaria, most of them in the U.S. and Europe. Moreover, the UFAC herbarium obtained a donation of duplicate specimens from the herbarium of INPA, the national Amazon research institute.

Acre and the rest of Southwestern Amazonia were indeed black holes for biodiversity in the early 1990s (Silveira et al., 1997) - some municipalities in the state were not represented by a single botanical collection -so the NYBG-UFAC program developed a plan to systematically sample all river basins and all municipalities in the state. Eventually, it was possible to triple the collecting density in the state, i.e., the number of plant collections per $100 \mathrm{~km}^{2}$. Today, Acre is considered one of the best-documented parts of the Amazonia (Vale \& Jenkins, 2012), despite the many gaps that remain in the floristic inventory of the state.

As now, human resources were the principal limitingfactor in studying the Acre flora. Marcos Silveira secured a series of PIBIC (Scientific Initiation) grants to support the most promising UFAC undergraduates. At the same time, the consortium succeeded in plugging nine students and young collaborators from Acre into a program run by the State University of New York (SUNY) - Albany that supported them in the U.S. for English-language instruction and master's degree programs; all returned to pursue their careers in Acre. The NYBG-UFAC collaboration also supported the field work of two ethnobotany students from the University of Florida and of two Brazil-based students who went on to do doctorates at the Yale School of Forestry and Environmental Studies. One of the research projects examined women's plant knowledge in extractive reserves (Kainer \& Duryea, 1992), and another constituted the first in-depth ethnobotanical study of the Kaxinawá (Ehringhaus, 1997), examining their uses of and relationships with plants in the black pepper family, Piperaceae.

Through these and other sources of support, the NYBG-UFAC consortium has facilitated master's and doctoral dissertation research for a number of young scientists from Acre and Rondônia; one of them was the curator of the UFAC herbarium as of 2018, and another was the project coordinator for grants from the Tinker Foundation and the Gordon and Betty Moore Foundation.

A key strategy not only for documenting the Acre flora but also for stimulating outside interest was called the Mobilizing Taxonomic Specialists Project. This project determined the most important plant families in the Acre flora, identified taxonomic 
specialists in those groups, and paid their expenses to come to Acre and conduct field work; in return, they identified the specimens of their families in the herbarium, provided an analysis of their families in Acre (endemism, new species, etc.), and offered a short course for UFAC undergraduates. This project, along with the thousands of duplicate specimens sent to many additional taxonomic specialists, made Acre a destination for botanical research; it also helped these specialists prepare the treatments of their families for the national flora catalogue (e.g., Daly, 2010).

The culmination of the NYBG-UFAC collaboration was the First Catalogue of the Flora of Acre, Brazil (Daly \& Silveira et al., 2008), a fully bilingual work that presented the botanical history, the vegetation types, strategies for documenting the flora, a checklist of the flora with over 4,000 species (contributing ten percent of the checklist of the flora of all Brazil), an analysis of the Acre flora's affinities, a glossary of more than 1,000 common names and their scientific equivalents, an analysis of common names for plants in Acre, and a discussion about the impacts of the NYBG-UFAC's program on conservation. The NYBG-UFAC team (mostly UFAC student interns at NYBG or in Acre) spent 18 months "cleaning" the data for the checklist before publication. The Catalogue helped establish the NYBG-UFAC partnership as the point of reference for botanical knowledge about Southwestern Amazonia.

A recent review of our knowledge of the Acre flora subsequent to the publication of the Catalogue showed that 500 species have been added to the known flora and that even five years later, on average every sixth identification of a plant collected in Acre yielded a species new to the flora, and every $35^{\text {th }}$ identification on average yielded a genus new to the flora (Medeiros et al., 2014). A second edition of the Catalogue will be published on-line to avoid instant obsolescence as new distribution records are recorded.

In addition to documenting Acre's plant species, the consortium carried out and supported projects that characterized some of the most salient vegetation types in Acre, including the tabocais (forests dominated by arborescent bamboos; Silveira, 2005 and Griscom et al., 2007); the "salão" vegetation occurring on the seeps of levees (Daly et al., 2006); and the complex vegetation formations on white sand (Daly et al., 2016). The consortium also supported studies of poorly known elements of the flora, such as epiphytes (Obermüller et al., 2012; 2014).

\section{Making use of the baseline}

\subsection{Participation in conservation initiatives}

From early on, the NYBG-UFAC program has been able to contribute to a number of conservation initiatives, mainly in Southwestern Amazonia, with substantive data not onlyabout species composition but also characterization of vegetation types and the ecology, abundance, uses, and distribution of salient species. The initiatives included the first two phases of the ZEE-Ecological-Economic Zoning project for Acre state (e.g., Acre, 2000) and identification of key gaps in botanical information aboutbiodiversity conservation in Southwestern (SW) Amazonia as part of a larger World Wildlife Fund analysis (Daly, 1996; Daly et al., 1996).

The botanical data produced by the NYBG-UFAC collaborative agreement (convênio) were 
essential to the development of the formal documents produced by state agencies and conservation organizations to justify the creation of the Chandless State Park (Passos et al. 2003) as well as the área de Relevante Interesse Ecológico (a category of protected area, known as a Area of Relevant Ecologic Interest) of Japiim Pentecoste in 2009, for which the consortium also contributed to the management plan. Original botanical data have been useful also for the development of management plans for protected areas in Acre, such as the Serra do Divisor National Park, the subsequently decreed Liberdade, Mógno, and Gregório State Forests, and the Rio Acre Ecological Station, which was created in 1981 but whose management plan was initiated only in 2005 by the non-governmental organization SOS Amazônia in partnership with IBAMA and with support from WWF-Brasil. The botanical data produced for the Serra do Divisor National Park also helped stimulate the creation of a "mirror park" across the border in Peru, the Parque Nacional de La Sierra del Divisor. In 2017, the consortium contributed data for the creation of the provisionally named Floresta Estadual do Afluente, will assist in its management plan.

The NYBG-UFAC program was invited to participate in two workshops organized by the Instituto Socioambiental entitled Evaluation and Identification of Priority Actions for Conservation, Sustainable Use, and Benefit-Sharing of Biodiversity in Amazonia, at the Basin-wide meeting in Macapá in 1999 and in the regional follow-up for SW Amazonia in 1992, where the NYBG-UFAC consortium coordinated and summarized the input of the biologists who participated. Similarly, the consortium provided part of the regional biodiversity context for another forest community-oriented effort, the Enciclopédia da Floresta ("Encyclopedia of the Forest") (Carneiro da Cunha \& Almeida, 2002; Daly \& Silveira, 2002; Silveira et al., 2002).

In 1996, the consortium established seven permanent $10,000 \mathrm{~m}^{2}$ transects in the Serra do Divisor National Park that are part of the inventory networks of RAINFOR and ATDN, and the data from these transects has contributed to a number of large-scale analyses of Amazon tree diversity (e.g., ter Steege et al., 2013).

\subsection{Resource management - botany and economic potential of non-timber forest products}

The NYBG-UFAC program participated in several of the broad workshops organized by the MAP (Madre de Dios-Acre-Pando) consortium in the early 2000s, but then the NYBG-UFAC program organized a botanically oriented "mini-MAP" entitled Rescue and Integration of Biodiversity Data in Southwestern Amazonia: A Workshop for Planning and Design, which took place in Puerto Maldonado between 3-5 June 2005 and included botanists and forest ecologists. That was the jumping-off point for forging a consortium of herbaria that are either situated in SW Amazonia or have significant holdings from the area (e.g., Santa Cruz, Bolivia and Missouri Botanical Garden); representatives of the SW Amazonia consortium herbaria convened in May 2009 at the Fazenda Experimental Catuaba of UFAC for a workshop specifically designed for developing skills for documenting flora, ranging from field photography to using the BRAHMS specimen-based software. The SW Amazon herbarium consortium met again in 2012, this time in Rio 
Branco, Acre. The expansion of the SW Amazonia consortium resulted in the signing of a collaborative research agreement between NYBG and the Universidade Federal de Rondônia (Federal University of Rondônia), which formalized the initiation of the Flora of Rondônia project. As in Acre before, this has already engendered published studies of new species (e.g., Daly, 2017) and analyses of vegetation types (Perigolo et al., 2017).

The seringueiros (rubber tappers) who made up most of the extractive populations in Acre had such a deep historical, economic, and cultural relationship with rubber, thatthe NYBG-UFAC's early efforts met with mixed success, because many of the rubber-tappers encountered at first, including the leadership of the Conselho Nacional dos Seringueiros, were more concerned about the continuation of subsidies that would allow them to keep on tapping rubber than about diversifying their economies.

Another factor that hindered early efforts was the lack of a baseline of knowledge about the plant resources of the entire Southwestern Amazon. Under these circumstances, some of the consortium's most important contributions consisted of determining the correct identities of resources often not a trivial matter - and obtaining useful information about their distribution, ecology, and commercial potential. The fact that SW Amazonia is an important center of diversity for a number of economic plant groups, including "cacao" (Theobroma spp.) and the timber tree "amarelão" (Aspidosperma spp.), implied that their taxonomy had to be resolved before their economic potential and management could be assessed,because multiple species of each occur in Acre, each with different physical and ecological properties (Daly \& Silveira et al. 2008). Other examples are the oleoresin "copaiba" (Copaifera spp.), whose taxonomy was resolved only in 2008 (Martins-da-Silva, 2008), and the fruit tree "cajá" (Spondias spp.), resolved in 2015 (Mitchell \& Daly, 1998; 2015).

Despite the impressive diversity of Acre's useful flora, studies of non-timber forest products (NTFPs) in Acre have been relatively scarce. Still, some substantive contributions, most of them supported at least in part by the NYBG-UFAC consortium, have investigated the uses and management of Acre's forest resources by rubber- tappers and indigenous groups (Kainer \& Dureya, 1992; Pinard,1993; Ming, 1995; Ming et al., 1997; Ehringhaus, 1997; Kainer et al., 1998; Ehringhaus et al., 2000; Rocha, 2002; and Campos \& Ehringhaus, 2003), and some studies examined market potential and market structure for NTFPs in Acre (Wallace, 2006; Wallace et al., 2006). Subsequently, a partnership established between UFAC and the now-extinct Acre State Executive Secretariat of Forests and Extractivism-SEFE (later SEF) catalyzed the initiation of ecological assessments of priority NTFPs in Acre. This effort was hindered somewhat by miscommunication and unfavorable circumstances. For example, a species of "pimenta longa" (Piper aduncum L., Black Pepper family) [Long pepper] was found to have high concentrations of safrole, which has been used in making insecticides and the fragrance piperol (https://en.wikipedia.org/ wiki/Safrole). The consortium was able to determine the identity of the species (there are at least 88 species of Piper in Acre), and some preliminary field studies explored small-scale plantations, but production levels and transportation costs made it impossible to compete commercially. An example of poor communication occurred when SEFE selected eight species of NTFPs for especially detailed 
examination for their potential without consulting with the NYBG-UFAC consortium. In fact, oneof the species do not occur in Acre and another is a medicinal plant for which no measures had been taken to secure the intellectual property rights for Acre's traditional communities.

Still, the same period has produced valuable surveys and studies of NTFPs, including some addressing management and economics issues presented in formats accessible to persons with primary education (e.g., Shanley, 2004), and the NYBG-UFAC consortium contributed to these efforts (e.g., Daly, 2004). Acute concerns about "biopiracy," i.e., theft of intellectual property and species representing germplasm resources, compounded by governmental protections for traditional communities, made it almost impossible to conduct ethnobotanical research in indigenous communities in Acre, with the result that virtually none of Acre's 14 ethnic groups have been studied ethnobotanically; this could be seen as a tragic lost opportunity for indigenous communities to record their traditional knowledge for their own posterity. One notable exception was the work of Ehringhaus (1997) and Campos (Campos \& Ehringhaus, 2003) with families of Kaxinawá on the upper Rio Tarauacá in a locality that did not have official status as an indigenous community.

\subsection{Botanical research applied to management of timber resources}

Placement of logging patios, felling techniques, and numerous other factors can have serious impacts on the sustainability of natural forest management for timber, but valid management is predica- ted on forest inventories and the tree identifications on which they are based. Meeting specific market demands and establishing acceptable harvest levels are extremely difficult if there is no reasonable certainty as to what is being harvested. Moreover, forest restoration hinges on our recognition and ecological knowledge of native species.

In 2008, not long after the publication of a paper that urged better monitoring of production forests (Euler, 2007), the NYBG-UFAC consortium was invited to visit and survey the flora in two separate forest management projects; one was private, owned by Laminados Triunfo Ltda., and the other was a Projeto de Assentamento Agroextrativista (PAE) [Agro-extractivist Settlement Project] settlement in Porto Dias. Both projects had been provisionally certified by the Forest Stewardship Council as sustainable. Analysis of the inventories on which their management plans were based showed that on both sites, $50-70 \%$ of the tree species were misidentified. In essence, identifications were based on common names obtained from unvetted field personnel that were then "translated" into scientific names using indexes (essentially glossaries) whose data were unverifiable. Considering that inventory protocols are similar across Amazonia, there is reason to believe that identifications arejust as inaccurate on other sites.

Key to this issue is the mateiro (also called parataxonomista or parabotânico), roughly translated in English as "woodsman," who has been an essential component of any effort related to plant resources in Amazonia for most of a century, starting probably with Adolpho Ducke in the 1930s. The ideal profile of a mateiro is someone who grew up in a traditional community with deep knowledge of the forest but also usually with elementary or so- 
metimes secondary education, and who has had the opportunity to learn from botanists about scientific names and basic botany. Mateiros are especially important in forest inventories, because botanists rely heavily on flower and fruit characteristics, but at any one moment the great majority of trees in tropical moist forests are producing neither flowers nor fruits. In contrast, traditional knowledge relies much more on bark, wood, sap, and to an extent leaf characters.

Projeto RADAMBRASIL (e.g., 1976-1977), Brazil's ambitious natural resource survey, trained a second generation of excellent mateiros in the 1970s, but as of 2018 most of them had retired or died, leaving a small cadre of fine second- and third-generation mateiros and a large number of people hired as mateiros but lacking at least some of the key skills.

The discovery that tree identifications in forest inventories are semi-fictitious was deeply troubling to the NYBG-UFAC consortium, which was already concerned about the dwindling number of mateiros available for participating in floristic work, so the consortium began developing strategies for improving inventories. These have included species pages (mostly pictorial profiles of timber species) (e.g., Obermüller et al., 2011), which place greater emphasis on leaf characteristics (Ellis et al., 2009) than flower or fruit characters, and field guides to complexes of species that have been confused with each other. Additional projects nearing completion are an illustrated glossary of botanical terms that are defined in simple Portuguese, and an image-driven key to timber species, the latter already including 85 species. The consortium has also developed recommendations for improved inventory protocols, in- cluding equipment, the composition of field teams, sampling methods, and quality control measures.

By far the NYBG-UFAC consortium's most important response has been to find ways to train new generations of mateiros. In November 2010, the consortium conducted a workshop in Rio Branco, Acre, that convened most of the living "super-mateiros" from across Amazonia, in order to signal the value of the mateiro, to call attention to the critical shortage of mateiros, and to explore solutions. In May 2011, the consortium conducted a pilot training course in Rio Branco, and in March 2012 the consortium conducted a second course in the FLONA (National Forest) Jamari. The latter was a 350-hour course with nine instructors covering basic plant morphology and taxonomy, tree identification strategies, forest inventory methods, sustainability certification, concepts of plant communities and conservation, field imaging of trees, and macroscopic identification of wood samples.

In August 2013, the consortium convened a follow-up workshop in Itapuã do Oeste, Rondônia entitled Tree Inventories in Amazônia: Experiences, Strategies and Plans. A Workshop for Botanical Identifiers in the Brazilian Amazon, with super-mateiros, botanists and representatives of the Brazilian Forest Service; UFRA (the Universidade Federal Rural da Amazônia) and EMBRAPA (Empresa Brasileira de Pesquisa Agropecuária) Amazônia Oriental and the Museu Goeldi in Belém; FUNTAC (Fundação de Tecnologia do Estado do Acre) in Rio Branco; INPA (Instituto Nacional de Pesquisa da Amazônia); the Rio de Janeiro Botanical Garden; IFAM (the trade school Instituto Federal do Amazônas); and IBAMA and UNIR (Universidade Federal de Rondônia) in Rondônia. The goals that time were to compare experiences in training mateiros 
and other field personnel and to seek mechanisms for propagating courses throughout Amazonia. The workshop was followed by a third training course of 240 hours in March 2014, in Saracá-Taquera National Forest (FLONA) in Pará. A fourth course was conducted in 2014-2015 in Ituxi-Lábrea, Amazônas, this one in partnership with IFAM.

Also in 2014, the Brazilian Forest Service (SFB) and NYBG signed an Act of Technical Cooperation (ACT) formalizing NYBG's advisory role with the SFB for improving forest inventories and tree identification; NYBG had been advising the SFB informally for several years prior to the ACT. Part of the work plan for the ACT includes helping to train the field personnel in every FLONA in Amazonia as it is opened to forest concessions.

In an effort to propagate the training course, in 2015 instructors from the mateiros course taught a group of professors at IFAC (Instituto Federal do Acre) to administer the course.

An intensive course conducted in the Tapajós region in November 2016 provided experience in conducting training in a hub for multiple protected areas and involving multiple regional institutions. That course, entitled Plant Collection and Preparation, was offered for representatives of the Tapajós-Arapiuns Extractive Reserve and the Tapajós National Forest, to train them as local agents for documenting flora in protected areas as a contribution to Brazil's National Program for Monitoring Biodiversity, the Programa Monitora.

Both the National Forest Inventory (IFN) of the SFB and the Chico Mendes Institute for Conservation of Biodiversity (ICMBio) have generated large numbers of inventory specimens requiring identification, and the consortium has discovered that the work party or mutirão is a highly effective vehicle not only for identifying specimens but also for training. The consortium provided instructors for a week-long, SFB-sponsored work party in Belém in April 2017 that also convened super-mateiros, students working for the IFN, and taxonomic specialists in key Amazon tree families, working through 7,000 specimens from inventories in three regions.

In the last quarter of 2017 and the beginning of 2018, the consortium group conducted 11 inventories across Amazonia for the ICMBio's Programa Monitora, working closely with the staffs of local conservation units and representatives of local communities, and in February 2018 the consortium conducted a work party to work on identifying 3,000 specimens at the Rio de Janeiro Botanical Garden, which was hosting these inventories.

\section{Future directions}

As noted, expansion of the consortium's efforts in SW Amazonia has included a recently signed collaborative agreement with UNIR, and the experienced field team in Acre has joined a number of botanical expeditions in Rondônia to help train undergraduates and field personnel from UNIR.

The consortium is now pursuing strategies to organize and support a capacity-building project in six clusters of federal conservation units across Amazonia, training community representatives in inventory and monitoring, and working with them as partners to build and improve tools for tree identification. The community partners will be trained to collect specimens, observe phenology, photodocument collected flora, and obtain special collections of material for DNA banks and Near 
Infrared (NIR) analyses, as well as samples for the national wood collection. In addition, their monitoring activities will devote extra attention to the dynamics and regeneration of key species that are economically and/or ecologically important in their region.

The skills acquired in the process will make those individuals invaluable - and employablefor forest monitoring, together withmany other activities in research and resource management. They will also be qualified for employment in the Brazilian Forest Service for monitoring of plots established for the National Forest Inventory; long-term employment for on-site management of conservation units; full-time employment with forest concessions in the National Forest system or other sustainable commercial enterprises; work as paraprofessionals and guides in scientific research projects and eco-tourism; and sustainable management of their own resources for income. This expertise is much in demand and will contribute significantly to a broader capacity-building strategy designed to strengthen community participation in conservation projects, including sustainable management of protected areas.

During the 30 years that have passed since the death of Chico Mendes, the NYBG-UFAC consortium has conducted botanical science and training geared toward contributing to the well-being of both Amazon forests and Amazon forest communities, respecting traditional knowledge and building scientific knowledge about the region's vast and complex plant resources. As the consortium increasingly focuses on forest communities as full participants and partners in projects devoted to inventory, management, monitoring, and conservation of forests throughout Amazonia, the consortium is are doing its small part to honor the legacy of Chico Mendes.

\section{Acknowledgments}

The authors thank once again the many people whose help and participation previously acknowledged in the First Catalogue of the Flora of Acre, Brazil (Daly Silveira et al. 2008); here we thank especially those who, besides the current authors, have been such a big part of our efforts since the publication of the Catalogue. They include Herison Medeiros de Oliveira, Edilson Consuelo de Oliveira, Wendeson Castro da Silva, Daniel da Silva Costa, Adriano da Silva Lima, Maurício Sacramento, Anna Fánzeres, Fernanda Piccolo Pierucci, Evandro José Muhlbauer, and Lívia Souza.

The authors also thank the consortium's generous funding sources, which over the years have included the U.S. National Science Foundation (DEB9300787), the Exxon Foundation, the Tinker Foundation, the W. Alton Jones Foundation, the Leo Model Foundation, the Overbrook Foundation, the Beneficia Foundation, the JRS Biodiversity Fund, and the Gordon and Betty Moore Foundation.

Finally, the authors deeply appreciate the careful editing and constructive suggestions of two anonymous reviewers.

\section{References}

Acre. Governo do Estado do Acre. Programa Estadual de Zoneamento Ecológico-Econômico do Estado do Acre. Vol. 1. Zoneamento ecológico-econômico: recursos naturais e meio ambiente - documento final. Rio Branco: SECTMA, 2000 . 
Carneiro da Cunha, M.; Almeida, M. B. (Eds.). Enciclopédia da Floresta. São Paulo: Companhia das Letras, 2002.

Campos, M.; Ehringhaus, C. Plant virtues are in the eyes of the beholders: A comparison of known palm uses among indigenous and folk communities of Southwestern Amazônia. Economic Botany, 57, 324-344, 2003.

Daly, D. C. Extractive reserves: a new great hope. Garden Journal, 14(6), 1415, 1718, 2021, 32, 1990.

Daly, D. C. Subregion of southwestern Amazon moist forest -- Upper Rio Purus in Acre and contiguous Bolivia -- Brazil, Bolivia. In: Olson, D. et al. (Eds.). 1996, loc. cit., p. 14-15.

Daly, D. C.; Foster, R.; León; B. Southwestern Amazon moist forest-Southwest, Juruá, Purus-Madeira -- Peru, Brazil, Bolivia. In: Olson, D. et al. (Eds.). 1996, loc. cit., p. 14-14.

Daly, D. C. Diversas outras espécies. In: Shanley, P.; Medina, G. (Eds.). loc. cit., 2004. p. 223-232.

Daly, D. C. 2010. Burseraceae. In: Forzza, R. C. et al. (Eds.). Catálogo de Plantas e Fungos do Brasil. Rio de Janeiro: Andrea Jakobsson Estúdio/Instituto de Pesquisas Jardim Botânico do Rio de Janeiro, 2010. p. 818-821. (also: http://floradobrasil.jbrj.gov.br)

Daly, D. C. A new peri-Amazonian species of Protium. Studies in neotropical Burseraceae XXI. Brittonia, 69, 465-469. doi: 10.1007/s12228-017-9479-z, 2017

Daly, D. C.; Lisboa, P. L. B. The Amazon, the Museu Goeldi and The New York Botanical Garden. In: Lisboa, P. L. B.; Daly, D. C. (Eds.). Trinta anos de cooperação entre o MG e o NYBG. Boletim do Museu Paraense Emílio Goeldi, sec. Bot., 7(2), 191198, 1991 [1993].

Daly, D. C.; Silveira, M. Aspectos florísticos da bacia do Alto Juruá: História botânica, peculiaridades, similaridades e importância para conservação. In: Carneiro da Cunha, M.; Almeida, M. B. (Eds.). loc. cit., 2002. p. 53-63.

Daly, D. C.; Foster, R.; León, B. Southwestern Amazon moist forest-Southwest, Juruá, Purus-Madeira -- Peru, Brazil, Bolivia. In: Olson, D. et al. (Eds.). 1996, loc. cit. p. II-13-14.

Daly, D. C.; Costa, D. P.; Melo, A. W. F. The "salão" vegetation of Southwestern Amazonia. Biodiversity and
Conservation, 15, 2905-2923, 2006.

Daly, D. C.; Silveira, M. \& collaborators. First Catalogue of the Flora of Acre, Brazil/Primeiro Catálogo da Flora do Acre, Brasil. Rio Branco: PRINTAC/EDUFAC, 2008.

Daly, D. C.; Silveira, M.; Medeiros, H.; Castro, W.; Obermüller, F. A. The white-sand vegetation of Acre, Brazil. Biotropica, 48, 81-89, 2016.

Ehringhaus, C. Medicinal uses of Piper spp. (Piperaceae) by an indigenous Kaxinawá community in Acre, Brazil: Ethnobotany, ecology, phytochemistry, and biological activity. Miami, Thesis (Master's) -- Florida International University, 1997.

Elisabetsky, E., Trajber, R., Ming, L. C. Manual de coleta de plantas medicinais em Reservas Extrativistas. Edição dos autores, 1995.

Ellis, B.; Daly, D. C.; Hickey, L.; Johnson, K. R.; Mitchell, J. D.; Wilf, P.; Wing, S. L. Manual of Leaf Architecture. Ithaca: Cornell University Press, 2009.

Euler, A.; Arguelles, M.; Silveira, M.; Waldhoff, P.; Ribaski, N.; Bitencourt, P.; Rocha, E.; Nagy, A.; Obermüller, F. A. Report on the Brazilian National Review of ITTO Guidelines for the Conservation and Sustainnable Use of Biodiversity in Tropical Forests. 2007.

Griscom, B. W.; Daly, D. C.; Ashton, P. M. S. Floristics of bamboo-dominated stands in lowland terra-firma forests of southwestern Amazonia. Bulletin of the Torrey Botanical Society, 134(1), 108-125, 2007.

Kainer, K. A.; Dureya, M. L. Tapping women's knowledge: Plant resource use in extractive reserves, Acre, Brazil. Economic Botany, 46, 408-425, 1992.

Kainer, K. A., Duryea, M. L.; Costa de Macedo, N.; Williams, $\mathrm{K}$. Brazil nut seedling establishment and autecology in extractive reserves of Acre, Brazil. Ecological Applications, 8, 397-410, 1998.

Martins-da-Silva, R. C. V., Pereira, J. F.; Lima, H. C. O gênero Copaifera (Leguminosae-Caesalpinioideae) na Amazônia brasileira. Rodriguésia, 59(3), 455-476, 2008.

Medeiros, H.; Obermüller, F. A.; Daly, D. C.; Silveira, M.; Castro, W.; Forzza, R. C. Botanical advances in Southwes- 
tern Amazonia: The flora of Acre, Brazil five years after the first Catalogue. Phytotaxa, 177(2), 101-117, 2014. doi: 10.11646/phytotaxa.177.2.2

Ming, L. C. Levantamento de plantas medicinais na Reserva Extrativista "Chico Mendes" - Acre. Botucatu, Tese (Ph.D. em Agronomia) -- Universidade Estadual Paulista-UNESP, 1995.

Ming, L. C. Plantas medicinais na Reserva Extrativista Chico Mendes, Acre. São Paulo: Fundação Editora UNESP, 2006.

Ming, L. C. Zoneamento de ambientes na Reserva Extrativista Chico Mendes, Acre. Recife: Editora NUPEEA, 2007.

Ming, L. C., Gaudêncio, P., Santos, V. P. Plantas medicinais: Uso popular na Reserva Extrativista Chico Mendes. New York: Rainforest Alliance, 1997.

Ming, L. C.; Amorozo, M. C. M.; Ferreira, A.B. (Eds.). Experiências etnobotânicas na Reserva Extrativista Chico Mendes, Acre. Feira de Santana: Sociedade Brasileira de Etnobiologia e Etnoecologia, 2018a.

Ming, L. C.; Hidalgo, A. F.; Chaves, F. C. M.; Haverroth, M.; Kinupp, V. F. Plantas para a malária e males associados no Rio Negro e Rio Purus: Aspectos etnobotânicos e agronômicos. Botucatu: Fundação de Pesquisas Agrícolas e Florestais, 2018b.

Mitchell, J. D.; Daly, D. C. The "tortoise's cajá" -- a new species of Spondias (Anacardiaceae) from southwestern Amazonia. Brittonia, 50, 447-451, 1998.

Mitchell, J. D.; Daly, D. C. A revision of Spondias (Anacardiaceae) in the Neotropics. Phytokeys, 55, 1-92, 2015.

Obermüller, F. A.; Daly, D. C.; Oliveira, E. C.; Sousa, H. F. T. P.; Oliveira, H. M.; Souza, L. S.; Silveira; M. Guia Ilustrado e Manual de Arquitetura Foliar para Espécies Madeireiras da Amazônia. Edição dos autores, 2011.

Obermüller, F. A.; Silveira, M.; Salimon, C. I.; Daly, D. C. Epiphytic (including hemiepiphytes) diversity in three timber species in the southwestern Amazon, Brazil. Biodiversity and Conservation, 21, 565-575, 2012.

Obermüller, F. A.; Freitas, L.; Daly, D. C.; Silveira, M. Patterns of diversity and gaps in vascular (hemi-)epiphyte flora of Southwestern Amazonia. Phytotaxa, 166(4), 259-
272, 2014. doi: 10.11646/phytotaxa.166.4.2

Olson, D.; Dinerstein, E.; Castro, G.; Maraví, E. (Eds.) Identifying Gaps in Botanical Information for Biodiversity Conservation in Latin America and the Caribbean. Washington, D. C.: World Wildlife Fund, 1996.

Passos, V. T. R.; Cerqueira, L; Silva, M.; Silveira, M. Documento de Defesa Técnica para a Criaçâo da Unidade de Conservação nas Campinaranas do Sudoeste Amazônico, 2003.

Perigolo, N. A.; Medeiros, M. B.; Simon, M. F. Vegetation types o the upper Madeira River in Rondônia, Brazil. Brittonia, 69, 423-446, 2017.

Pinard, M. Impacts of stem harvesting on populations of Iriartea deltoidea (Palmae) in an extractive reserve in Acre, Brazil. Biotropica, 25, 2-14, 1993.

Prance, G. T., Nelson, B. W.; Silva, M. F.; Daly, D. C. Projeto Flora Amazônica: eight years of binational botanical expeditions. Acta Amazônica, 14(12), Supl., 530, 1984.

RADAMBRASIL. Levantamento de Recursos Naturais. Vols. 8-18. Rio de Janeiro: Ministério de Minas e Energia, 1976-1977.

Shanley, P.; Medina, G. (Eds.). Frutiferas e Plantas Úteis na Vida Amazônica. Belém: Editora Supercores, CIFOR/ IMAZON, 2004.

Silveira, M. A floresta aberta com bambu no sudoeste da Amazônia: Padrões e processos em múltiplas escalas. Rio Branco: Editora da UFAC, 2005.

Silveira, M.; Paula, N. M. C., Brown, I. F.; Borges, H. B. N.; Daly, D. C.; Ferreira, L. A. Os "buracos negros" da diversidade -- Estudos no Acre revelam precariedade do conhecimento sobre a flora amazônica. Ciência Hoje, 22(128), 64-65, 1997.

Silveira, M.; Torezan, J. M.; Daly, D. C. Caracterização ambiental e diversidade arbórea na bacia do Alto Juruá. In: Carneiro da Cunha, M.; Almeida, M. B. (Eds.). loc. cit., 2002. p. 65-75.

Siviero, A.; Ming, L. C., Silveira, M., Daly, D. C., Wallace, R. H. (Eds.) Etnobotânica e Botânica Econômica do Acre. Rio Branco: Editora UFAC, 2016. 
ter Steege, H. et al. [multiple authors including Daly, D. C. $\&$ Silveira, M.]. Hyperdominance in the Amazonian Tree Flora. Science 342, 2013. doi: 10.1126/science.1243092

ter Steege, H. et al. [incl. D. C. Daly] Hyperdominance in the Amazonian tree flora. Science 342 (DOI: 10.1126/ science.1243092). Vale, M .M.; Jenkins, C. N. Across-taxa incongruence in patterns of collecting bias. Journal of Biogeography, 39, 1744-1748, 2012.

Wallace, R. C. The traditional marketing system in the three communities in the Chico Mendes Extractive Reser$v e$ : implications for the extraction and marketing of other non-timber forest products. http://www.nybg.org/bsci/acre/ www2/traditional.html. 10/10/2006.

Wallace, R. C.; Daly, D. C.; Silveira, M. Developing regional markets for forest products in southwestern Amazonia. http:// www.nybg.org/bsci/acre/www1/markets.html, 10/10/2006. 